\title{
Gonad and gut indices of European Sea Urchin (Paracentrotus lividus, L, 1816) in Çesme Bay of Eastern Agean Sea
}

\section{Çeşme Körfezi’ndeki (Doğu Ege Denizi) Avrupa Deniz Kestanesi’nin (Paracentrotus lividus, Lamarck, 1816) gonad ve mide indeksleri}

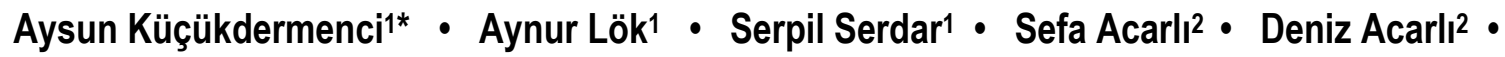 \\ Harun Yıldız² • Selçuk Yiğitkurt' ${ }^{1}$ Ali Kırtık1
}

1 Ege University, Faculty of Fisheries, 35100, Bornova, izmir, Turkey

2 Çanakkale Onsekiz Mart University, Marine Science and Technology Faculty, 17100, Çanakkale, Turkey

*Corresponding Author: aysun.kose@ege.edu.tr

\section{How to cite this paper:}

Küçükdermenci, A., Lök, A.,Serdar, S.,Acarlı, S.,Acarlı, D.,Yıldı, H.,Yiğitkurt, S.,Kırtık, A., 2015. Gonad and gut indices of European Sea Urchin (Paracentrotus lividus, L, 1816) in Çesme Bay of Eastern Agean Sea. Ege J Fish Aqua Sci 32(2): 59-63. doi: 10.12714/egejfas.2015.32.2.02

\begin{abstract}
Özet: Bu çalışmanın amacı Ege Denizi kıyılarında bulunan Paracentrotus lividus populasyonunun mide ve gonad verimini belirlemek ve gonad indeks değişimi üzerine çevresel koşulların etkisini değerlendirmektir. Bunu gerçekleştirmek içinde, oniki ay boyunca örnekler toplandı ve biyometrik ölçümler yapııdı. Kasım ve Mayıs ayları arasında su sıcaklığı çok fazla değişmemesine rağmen yaş gonad indeksi en soğuk aylardan biri olan Nisan ayında $\left(14^{\circ} \mathrm{C}\right)$ pik $(6.22 \pm 0.56 \%)$ yaptı. Bu çalışmada, su sıcaklığının düşmesi gonad üretimini etkilediği fakat gonadı etkileyenin sadece sıcaklık olmadığı çünkü diğer soğuk aylar boyunca gonad

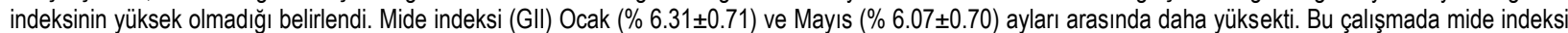
ilkbaharda sonbahara gore daha yüksekti.
\end{abstract}

Anahtar kelimeler: Paracentrotus lividus, gonad, mide, sıcaklık, besin

\begin{abstract}
The objective of present study is to determine the gut and gonad yield of Paracentrotus lividus populations occuring along Aegean Sea coastline and to evaluate of the environmental conditions on the gonad indices variability. To achieve this, samples were gathered during twelve months and biometric measurements were done. The wet gonad index peaked $(6.22 \pm 0.56 \%)$ in one $\left(A p r i l-14^{\circ} \mathrm{C}\right)$ of the coldest months (between November-May) even though water temperature was not change so much between November and May. It is determined that decreasing temperature affected gonad production but temperature is not only one factor effecting of gonad because of gonad indices were not high during the other cold months (between November-May) in this study. The higher gut index (GII) values were observed between January $(6.31 \pm 0.71 \%)$ and May $(6.07 \pm 0.70 \%)$. The gut index was higher in spring than in fall in this study.
\end{abstract}

Keywords: Paracentrotus lividus, gonad, gut, temperature, food

\section{INTRODUCTION}

Physiological indices such as those defining the condition of the gonad and gut can be used to demonstrate nutritional situation and habitat quality (Murillo-Navarro and JimenezGuirado, 2012). The abiotic factors and the physiological indices all have an annual cycle and thus, they are all correlated naturally. Since the biomass of algal populations which diets of echinoderms fluctuates throughout the year, the availability of food resources for sea urchins is not completely consistent (Murillo-Navarro and Jimenez-Guirado, 2012). Therefore body indices can be differentiated through the year. Ebert (1988) suggest that as sea urchin grow, lantern, the body wall, and gut assume relatively smaller fractions of total wet weight whereas the coelomic fluid and gonad composite become relatively larger. The variability in gonad condition has been described by different authors. Byrne (1990) indicated the gonad growth occurs during the coldest part of the year, coinciding with months with shorter days in Ireland. In the Mediterranean Sea, Lozano et al. (1995) concluded that the maturation of the gonads occurs during the winter and the main spawning during the spring or early summer, suggesting that the abundance of phytoplankton has an impact on the start of lay. Gonad quality is important for gonad yield in the commercial roe industry (Lozano et al., 1995). Gonad colour affects the gonad quality. Because the price of sea urchin roe is influenced by colour, texture, and taste. The gonad colour can range from a blond yellow to a dark orange or almost red depending on the local 
market preferences. Dark brown or pale coloured gonads are not as covetable to the market.

The gut has a role in storing nutrients for transfer to the gonads for gametogenic objectives. The food consumption of the sea urchin impacts the yield of the gut (Lawrence et al., 1965). In general, sea urchin roe production was highest on the most preferred algal foods, usually kelps. On barren grounds, urchins produce significantly more roe in areas dominated by macrophytes than conspecifics (Vadas, 1977).

The request for high quality sea urchin roe has led to an extensive exploitation of sea urchin populations all over the world during the last three decades (Keesing, 1998; Andrew et al., 2002). In Turkey the situation is different because the sea urchin $P$. lividus roe has not known so much on the domestic market and there have been a number of attempts to export urchin roe to overseas markets such as Japan, but only a small amount has been exported. Fishing and aquaculture in Turkey require significant knowledge and resources about sea urchins because of the variable quality and wide distribution of animals that have good quality. The main objective of the present investigation was to study a sea urchin population from the shoreline near the city of Izmir (Aegean coast), in order to understand their state of gonad development throughout the year and temporal relationship (monthly) between the gonad and gut index.

\section{MATERIAL AND METHOD}

Sea urchin individuals, $P$. lividus, were gathered between July 2003 to June 2004 from Çesme (038012"77'N; 026025"46'E), Izmir. On each sampling time, 60 specimens with test diameter were randomly collected by hand monthly at 0.5-1m depth. Sampled specimens were transported alive, in a container with seawater; they were processed immediately in Urla research laboratory. At the sampling site, the surface water temperature was measured with a mercury thermometer (ranged -10 to $100 \pm 0.5^{\circ} \mathrm{C}$ ), salinity (\%) was determined with hand refractometer (NOW-Tokyo) every sampling time in Çesme.

The horizontal test diameter (perpendicular to the oralaboral axes; with and without spines) of sea urchins were measured using sliding callipers (IP 66-Mitutoyo Absolute). After 5 min of drainage on a filter paper, each sea urchin was wet live weighted with $0.01 \mathrm{~g}$ precision electronic laboratory scales (GE 412 Sartorius) and then sea urchins were dissected on peristominal membrane and gonad, gut were wet weighed. After weighing the gonad lops, gonad colour was determined by the same observer in natural daylight. Colour was assessed by ranking each gonad in categories from unacceptable to most desirable: dark orange (DO), bright orange (BO), yellow orange (YO) and mango orange (MO), respectively (Shpigel et al., 2005).
To eliminate differences due to smaller and bigger specimens, we considered to calculate the indices only specimens between $30-40 \mathrm{~mm}$. In these samples, wet gonad index (WGI) and wet gut index were calculated as the ratio between the wet weight of the component (gonad or gut) and the total wet weight of the sea urchin expressed in $\mathrm{mg}$ :

WGI $(\%)=($ Wet weight of gonad/Total wet weight of sea urchin $) \mathrm{X} 100$ (Agatsuma, 1998).

GII $(\%)=($ Wet weight of gut $/$ Total wet weight of sea urchin $) \times 100$ (Guillou and Michel, 1994).

\section{Statistical Analysis}

Results were expressed as the mean \pm standard error. The biometric measurements and the physiological indices were made of using by Microsoft Excel Program. Indices of the gonad were normalized using the arcsine transformation and then gonad subjected to analysis of variance (ANOVA) with time as factors and post-hoc LSD multiple mean comparison test were used with the software STATISTICA 7.1. All statistical significance tests were at the $p<0.05$ levels (Watts et al., 1998).

\section{RESULTS}

At Çesme, mean size of $P$. lividus varied significantly over time (one-way ANOVA, $p<0.05$ ) and total sea urchin size frequency fluctuated from $10 \mathrm{~mm}$ to $70 \mathrm{~mm}$. In size frequency figures, the test diameters of the total number echinoids samples; $40 \pm 10 \mathrm{~mm}$ test diameter individuals were usually obtained however in particular small numbers of sea urchins with test diameters of $70 \mathrm{~mm}$ were found in May 2004. Small urchins were the most abundant between February and July, especially in June, where a third of the total numbers were small. The size-frequency graphs illustrate a decrease at medium size ( 3 to $4 \mathrm{~cm}$ in diameter) from February to June. There were temporal changes in the abundance of $P$. lividus with significantly more animals first month and after 9 month from the start of the study (Figure 1).

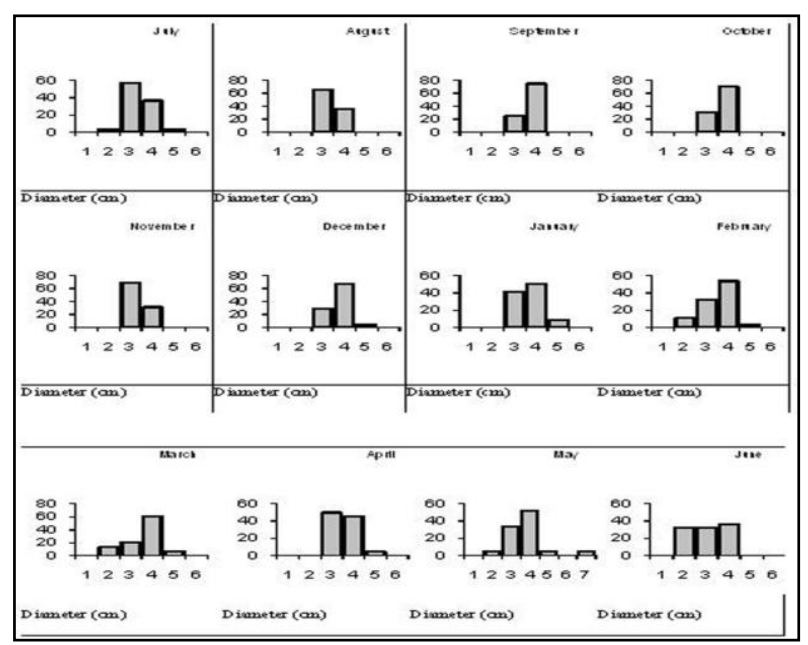

Figure 1. Size frequency of $P$. lividus in the sampling site 
Monthly changes in the gonad colour of $P$. lividus are showed in Figure 2. Gonad colour ranged from dark orange (intermediate quality) to a mango-orange or bright orange (higher quality) throughout the year. Bright orange colour was observed through the year and it was maximum in April (45\%). Mango orange was maximum in August (31.25\%) and then a decrease was observed from October to February.

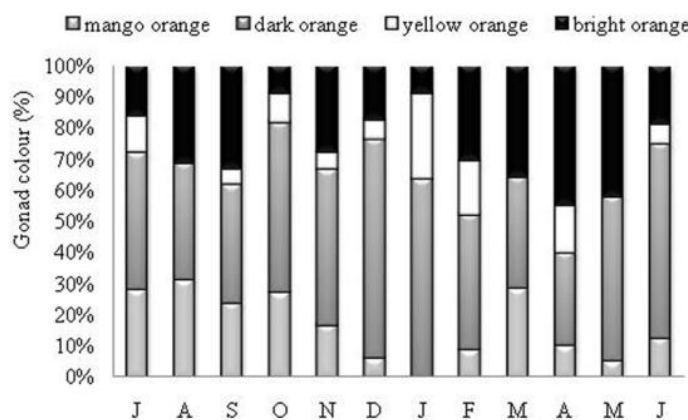

Figure 2. Histogram showing the changes in the gonad colour of $P$. lividus. Values are the percent of gonads in each colour category. Mango orange is most desirable; bright orange and yellow orange are acceptable; dark orange and pale yellow are unacceptable.

Over the period studied, there were significant differences between months in GII $((p \leq 0.05) \%$ annual mean \pm $\mathrm{se}=4.00 \pm 0.57$ ). The lowest values occurred in late summer (August) and autumn (September, October, November) and then the increase was observed through the late winter and spring. The higher GII values were observed between January $(6.31 \pm 0.71 \%)$ and May $(6.07 \pm 0.70 \%)$ (Figure 4).

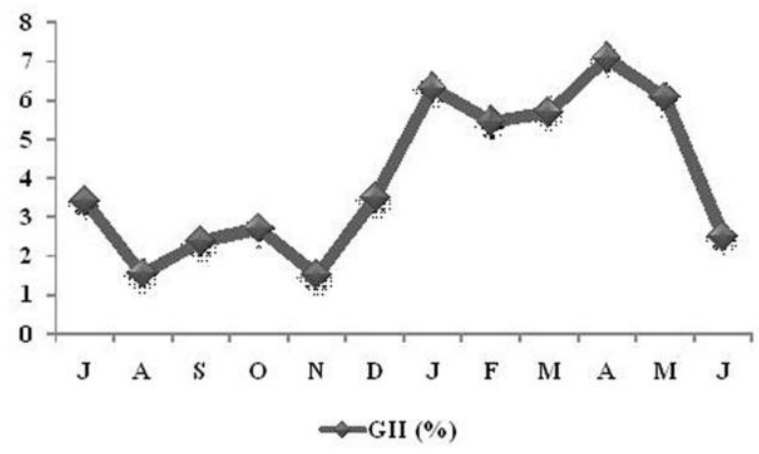

Figure 4. Monthly changes (mean \pm se) in the gut (GII) of the sea urchins

\section{DISCUSSION}

Many processes such as competition, natural predation, recruitment, early mortality and food availability influence the size and viability of sea urchin populations (Jangoux, 1987; Turon, 1995; Sala and Zabala, 1996; Lopez et al., 1998). In shallow Mediterranean rocky reefs, intense exploitation
Figure 3 shows the mean annual changes in seawater temperature and wet gonad index (WGI) in the sampling site. The minimum WGI values were calculated in October $(1.45 \pm 0.20 \%)$ and in January $(1.46 \pm 0.35 \%)$. The WGI has one peak in April $(6.22 \pm 0.56 \%)$. Although there is not significant relationship between $W G I$ and temperature $(r 2=0.06)$ the lowest temperature values were obtained during December and April, coinciding with the highest GSI values.

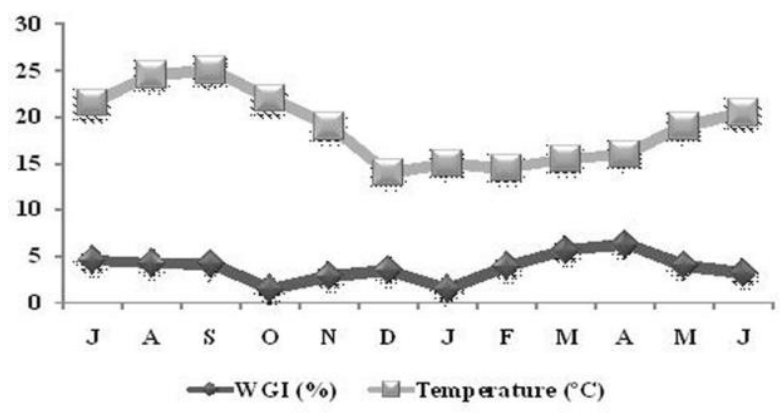

Figure 3. The change of wet gonad index (WGI) and temperature

reduces the biomass and mean size of $P$. lividus (Guidetti et al., 2004). Conversely, accordingly to the results of this study, the mean size was not low because commercial sea urchin harvesting was not so much in this area. The size distributions suggest that the increase in $P$. lividus abundance in sand and boulder habitat at Cesme from February to July could be due to the February more recruitment episode whereas the later decrease until January was coupled to lower recruitment rates.

Gonad indices were changed according to regions and species, such as lower than $8 \%$ (Spirlet et al., 1998) and 6$12 \%$ (Spirlet et al., 2000) in France, 4.1-5.6\% for P. lividus in Algeria (Soualili and Guillou, 2009). According to our field observations, similar results (1.45\%-6.2\%) were obtained with others. Gonad yield varies with environmental conditions (Sanchez-Espana et al., 2004; Byrne, 1990) temperature (Spirlet et al., 2000), food availability (Senaratna et al., 2005) and photoperiod (Shpigel et al., 2005). Siikavuopio et al., (2006) stated that the adult green sea urchin (Strongylocentrotus droebachiensis) maximum gonad growth appeared to occur at a higher temperature $\left(10^{\circ} \mathrm{C}, 12^{\circ} \mathrm{C}, 14^{\circ} \mathrm{C}\right)$ in summer than winter $\left(4^{\circ} \mathrm{C}, 6^{\circ} \mathrm{C}, 8^{\circ} \mathrm{C}\right)$ in Norway. It has been demonstrated that $P$. lividus have a relationship between gonadal growth and decreasing temperature for both Mediterranean and Irish population and gonadal growth occurs during the coldest months in P. lividus in Ireland. (Byrne, 1990). Similarly, Crapp and Willis (1975) indicated that the gonad indices of $P$. lividus rose to peak values in late winter and late summer. In this study, gonad index peaked in one (April- $14^{\circ} \mathrm{C}$ ) of the coldest months (between November-May) even though 
water temperature was not change so much between November and May. So we can say decreasing temperature affected gonad production but temperature is not only one factor effecting of gonad because the gonad indices were not high during the other cold months (between November-May).

In general, $P$. lividus species diets contained largely of seaweeds and food consumption affects the size of the gut (Lawrence et al., 1965). The gut index was higher in spring than in fall in this study (like as WGI). These differences are probably related to food availability and water content of gut. One possibility can be the lack of high quality algae in the subtidal during fall. Nutrients might be stocked in any one of the components of the sea urchin body, for example, the gonad, the gut, or body wall (Lawrence et al., 1965). Therefore food availability and quality affect gonad index and an increase in

\section{REFERENCES}

Agatsuma, Y., (1998). Aquaculture of the sea urchin (Strongylocentrotus nudus) transplanted from coralline flats in Hokkaido, Japan. Journal of Shellfish Research Vol. 17, No: 5, 1541-1547.

Andrew, N.L., Agatsuma, Y., Ballesteros, E., Bazhin, A.G., Creaser, E.P. Barnes, D.K.A., Botsford, L.W., Bradbury, A., Campbell, A., Dixon, J.D., Einarsson, S., Gerring, P., Bebert, K., Hunter, M., Hur, S.B., Johnson C.R., Juinio-Menez, M.A., Kalvass, P., Miller, R.J., Moreno, C.A., Palleiro J.S., Rivas, D., Robinson, S.M.L., Schroeter, S.C., Steneck, R.S., Vadas R.L., Woodby, D.A., Xiaoqi, Z., (2002). Status and management of world sea urchin fisheries. Oceanography and Marine Biology Annual Review 40, 343-425

Byrne, M., (1990). Annual reproductive cycles of the commercial sea urchin Paracentrotus.lividus from on exposed intertidal and a sheltered subtidal habitat on the west coast of Ireland. Marine Biology, 104: 275-289. doi: 10.1007/BF01313269

Crapp, G,B., Willis, M.E., (1975). Age determination in the sea urchin Paracentrotus lividus (Lamarck) with notes on the reproductive cycle. Journal of the Experimental Marine Biology and Ecology, 20: 157-178. doi: 10.1016/0022-0981(75)90021-0

Ebert, T.A., (1988). Allometry, design and contraint of body components and shape in sea urchins. J. Nat Hist 22: 1407-1425. doi: 10.1080/00222938800770841

Guidetti, P., Terlizzi, A., Boero, F., (2004). Effects of the edible sea urchin, Paracentrotus lividus, fishery along the Apulian rocky coast (SE Italy, Mediterranean Sea). Fisheries Research 66, 287-297. doi: 10.1016/S0165-7836(03)00206-6

Guillou, M., Michel, C., (1994). The influence of environmental factors on the growth of Sphaerechinus granularis (Lamarck) (Echinodermata: Echinoidea) Journal of the Experimental Marine Biology and Ecology, 178: 97-111. doi: 10.1016/0022-0981(94)90227-5

Jangoux, M., (1987). Disease of Echinodermata, I. Agents microorganisms and protistans Dis. Aquat. Org. 2, 147-162. doi: 10.3354/dao002147

Keesing, J.K., Hall, K.C., (1998). Review of harvest and status of word sea urchin fisheries point to opportunities for aquaculture J. Shellfish Res. 17: 1505-1506.

Kelly, M.S., Cook, E.J., (2001). The ecology of Psammechinus miliaris. Edible Sea Urchins: Biology and Ecology. J. M. Lawrence, Elsevier Science: $217-$ 224. doi: 10.1016/s0167-9309(01)80014-4

Lawrence, J.M., Lawrence, A.L., Holland, N.D., (1965). Annual cycle in the size of the gut of the purple sea urchin, Strongylocentrotus purpuratus (Stimpson). Nature 205: 1238-1239. doi: 10.1038/2051238a0 nutrients even in winter months results increase in gonadal mass (Kelly and Cook, 2001). This probably occurs in this study because the increase of WGI during colder months (winter) was detected.

The sea urchin industry is based on the production of marketable gonads. Colour in sea urchin gonads is recognized as an important quality factor in marketability, with bright mango or yellow orange being the most desirable colour. In current study, the highest proportion of urchins exhibiting mango orange (the most desirable) gonad occurred during the second (2.) and seventh (7.) sampling dates (August and January) when are most suitable for market sea urchin gonads in west of Turkey. This intense gonad colouration can be attributed to high bioavailability of the algal pigments in Cesme sea urchin gonads.

Lopez, S., Turon, X., Monterio, E., Palacin, C., Duarte, C.M., Tarjuelo, I., (1998). Larval abundance, recruitment and early mortality in Paracentrotus lividus (Echinoidea). Interannual variability and planktonbenthos coupling. Mar Ecol Prog Ser 172:239-251. doi:10.3354/meps172239

Lozano, J., Galero, J., Lopez, S., Turon, X., Polacin, C., Morera, G., (1995). Biological cycles and recruitment of Paracentrotus lividus (Echinodermota: Echinoidea) in two contrasting habitats, Mar. Ecol. Prog. Ser. 122 197191. doi: $10.3354 /$ meps 122179

Murillo-Navarro, R., Jimenez-Guirado, D., (2012). Relationship between algal food and gut and gonad conditions in the Mediterranean sea urchin Paracentrotus lividus (Lam.) Mediterranean Marine Science 13/2, 227238. doi: $10.12681 / \mathrm{mms} .302$

Pearce, C.M., Daggett, T.L., Robinson, S.M.C., (2002). Effect of protein source ratio and protein concentration in prepared diets on gonad yield and quality of the green sea urchin, Strongylocentrotus droebachiessis Aquaculture 214. 307-332. doi: 10.1016/S0044-8486(02)00041-8

Sala, E., Zabala, M., (1996). Fish predation and the structure of the sea urchin Paracentrotus lividus populations in the NW Mediterranean. Marine Ecology Progress Series, 140: 71-81. doi: 10.3354/meps140071

Sanchez-Espana, A,I., Martinéz-Pita, I., Garcia, F.J., (2004). Gonadal growth and reproduction in the commercial sea urchin Paracentrotus lividus (Lamarck, 1816) (Echinodermata: Echinoidea) from southern Spain Hydrobiologia. Volume 519, Numbers 1-3. Pages: 61-72. doi: $10.1023 / b$ :hydr.0000026485.40173.02

Senaratna, M., Evans, L.H., Southam, L., Tsvetnenko, E., (2005). Effect of different feed formulations on feed efficiency, gonad yield and gonad quality in the purple sea urchin Heliocidaris erythrogramma. Aquatic Science Research Unit, Muresk Institute, Curtin University of Technology, Perth, W. A., Australia. doi: 10.1111/j.1365-2095.2005.00340.x

Shpigel, M., Mcbride, S.C., Marciano, S., Ron, S., Ben-Amotz, A., (2005). Improving gonad colour and somatic index in the Eurepan sea urchin Paracentrotus lividus. Aquaculture 245: 101-109. doi: 10.1016/j.aquaculture.2004.11.043

Siikavuopio, S.I., Chritiansen, J.S., Dale, T., (2006). Effects of temperature and season on gonad growth and feed intake in the gren sea urchin (Strongylocentrotus droebachiensis). Norwegian Institute of Fisheries and Aquaculture Research, N-9018, Tromso, Norway.

Soualili, D., Guillou, M., (2009). Variations in the reproductive cycle of the sea urchin Paracentrotus lividus in three differently polluted locations near Algiers (Algeria). Marine Biological Association of the United Kingdom. Vol: 2 
Spirlet, C., Grosjean, P., Jangoux, M., (1998). Reproductive cycle of echinoid Paracentrotus lividus:analysis by means of the maturity index. Invertebrote Reproductian and Development, 34:1-69-81 Daleban, Philadelphia.

Spirlet, C., Grosjean, P., Jangoux, M., (2000). Optimization of gonad growth by manipulation of temperature and photoperiod in cultivated sea urchins, Paracentrotus lividus (Lamarck) (Echinodermata). Aquaculture, 185: 8599. doi: 10.1016/S0044-8486(99)00340-3
Vadas, R.L., (1977). Preferential feeding on optimization strategy in sea urchins. Ecol. Monogr 47:337-371. doi: 10.2307/1942173

Turon, X., Giribet, G., Lopez, S., Palacin, C., (1995). Growth and population structure of Paracentrotus lividus (Echinodermata: Echinoidea) in two contrasting habitats. Mar. Ecol. Prog. Ser. 122, 193-204. doi: 10.3354/meps122193

Watts, S.A., Boettger, S.A., McClintock, J.B., Lawrence, J.M., (1998). Gonad production in the sea urchin Lytechinus variegatus (Lamarck) fed prepared diets. J. Shellfish Res. 17: 1591-1595. 